\title{
EFFECT OF DELTAMETHRIN ON LIVER AND KIDNEY FUNCTION OF CLARIAS LAZERA FISH
}

\author{
${ }^{1}$ M. A. Aziz , ${ }^{2}$ Hanaa M. Hegazi, ${ }^{3}$ Menha M. Abd EL-Khalik, \\ and ${ }^{4}$ Manal M. A. Taha
}

${ }^{1}$ Department of Pharmacology, and 2Forensic Medicine and Toxicology, Faculty of Veterinary Medicine, Kafrelsheikh University, Egypt.

${ }^{3}$ Department of Biochemistry, and Feed Deficiency Diseases, Animal Health Research Institute, Dokki, Cairo, Egypt.

${ }^{4}$ Department of Public Health and Zoonotic Diseases, Directorate of Veterinary Medicine, Kafr El- Sheikh, Egypt.

\section{ABSTRACT}

A total number of 160 apparently healthy male catfish (Clarias lazera) weighed 95-105 gm, and with total length of 21-25 cm were exposed to deltamethrin (DM) concentrations of $0.5 \mathrm{ug} / \mathrm{L}$, for one week, and 0.02, and $0.01 \mathrm{ug} / \mathrm{L}$ for 4 weeks. Serum and internal organs (liver, and kidney) samples were obtained for the determination of both liver and kidney functions. Liver function tests revealed a non-significant difference in serum total bilirubin, serum total globulins (S.G.), serum albumin/globulin $(A / G)$ ratio, serum triglycerides $(T G)$ level, serum alanine aminotransferase activity (S.ALT), serum alkaline phosphatase activity (S.ALP), and a significant increase in serum albumin (S.A.), serum total protein (S.T.P.), serum aspartate aminotransferase (S.AST), and lactate dehydrogenase (S.LDH) activities, and a significant decrease in serum total cholesterol and serum total lipids (TL) level, by the exposure to the concentration 0.5 ug/L of DM for one week. There was also a significant increase in serum total bilirubin, S. AST, S. ALT, S.ALP, and serum LDH activities and a significant decrease in S.A. level, S.T.P. , serum A/G 
ratio, and a non-significant difference in S.G. content, by both concentrations 0.01, and $0.02 \mathrm{ug} / \mathrm{L}$ of DM. The concentration 0.01 ug/L of DM only significantly increased serum cholesterol, TG, and $T L$ levels, while, the concentration $0.02 \mathrm{ug} / \mathrm{L}$ significantly decreased the serum cholesterol, TG, and TL levels. Liver tissue showed excess of melano-machrophage centers (MMCs), congestion, odema and lymphocytic infiltrations after acute exposure to the concentration 0.5 ug/L of DM for one week, while After chronic exposure there were congestion, hepatocytic degeneration and necrosis which were accompanied with excess of MMCs. Kidney function test revealed a significant increase in serum urea, serum creatinine (S.Cr.) and serum uric acid level by the concentration $0.5 \mathrm{ug} / \mathrm{L}$ for one week, and 0.02 $u g / L$ for 4 weeks, and only and a significant increase in both urea and uric acid levels by the concentration $0.01 \mathrm{ug} / \mathrm{L}$ for 4 weeks. The renal tubules were damaged with congestion of the various glomerular as well as intertubular blood vessels in addition to several areas of hemorrhages and lymphocytic infiltration after acute exposures, while the posterior kidneys suffered damage of the glomeruli with several tubular degenerations and necrosis in addition to an excess of mononuclear cell reactions after the chronic exposure to the high concentration $0.02 \mathrm{ug} / \mathrm{L}$ of DM.

Keywords: Deltamethrin: Toxicity: catfish (Clarias lazera): Liver function: Kidney function Histopathology.

\section{INTRODUCTION}

Our land suffers from pollution, which is one of the most deleterious agents to the biological life. Pesticides are foreign chemicals intentionally released to the environment with bad dramatic pollutant consequences (Landis and Hoyu, 1995). Water and soil are the ultimate sinks for most pesticides used. Regarding to that, nearly three quarters of 
the earth's surface is covered by water, and suspended soil particles in water represent an interface between water and soil, special attention must be given to fish as the main target of water pollutants (Noga, 1996). Deltamethrin is a type II world wide common extensively used alpha cyano pyrethroid insecticide in agriculture, home pest control, protection of food stuff, and disease vector control (Yousef et al., 2006). It is also the first potent and photostable insecticide belonging to type II pyrethroid group (Velisek et al., 2006). Although initially thought to be least toxic, a number of recent reports showed its toxicity in mammalian, and non-mammalian laboratory and wild life animal species. In fish it's a potent stress-inducing agent (Rehman et al., 2006) The incidence of deltamethrin pollution in the aquatic environment and its toxic effect to edible fish resulted from the direct application during the control of aquatic insects or indirect pollution as a drift from aerial and land application or the leaching into ground water (EL - Basyouni, 1985). Deltamethrin was responsible for devastation of 30 tons of eel (Anguilla anguilla), in Lake Balaton, Hungary, in the summer of 1995. Also a similar eel death by deltamethrin was recorded in 1991, (Nemcsok et al., 1999). Many warnings and more questions about the role of deltamethrin in environmental pollution were recorded. However, not much research has been done on the impact of this insecticide on the aquatic ecosystem.

\section{.MATERIAL AND METHODS}

\section{Insecticide: Deltamethrin commercial formulation $5 \% \mathrm{w} / \mathrm{v}$ :}

Fish and Aquaria: A total number of 160 apparently healthy male catfish (Clarias lazera) weighed 95-105 gm, and with total length of 21$25 \mathrm{~cm}$. The fish were obtained from a private fishery in Kafr EL Sheikh. Fish were kept in twelve chlorine free tap water (ASTM, 1980) full glass 
aquaria $(100 \times 30 \times 40 \mathrm{~cm})$ and were acclimatized to the laboratory conditions for 2 weeks before being used (Floyd, 1993). Continuous aeration was maintained using an air pump. The water temperature was thermostatically adjusted at $28 \mathrm{C}$ (Floyd, 1993 a) using an electrical heater. The PH of water was about 6.9-7.5 throughout the experiment. Fish were fed according to Tucker and Robinson, (1990) on a commercial fish diet in the form of dry floating pellets at a rate of $3 \%$ of the body weight, two times daily. The pellets consisted of a mixture of fish meal, wheat flour, wheat germ, and other grain products, and vitamins, which contained $32.0 \%$ crude protein, $3.0 \%$ crude fat, $5.6 \%$ crude fiber, $12.1 \%$ crude ash, vitamins ( $A, B_{1}, B_{2}, C, D_{3}$, and $\left.{ }_{E}\right)$, and minerals supplements.

Kits for biochemical reactions: kits used for determination of serum lactate dehydrogenase activity(HUMAN), serum cholesterol (ELITECH), serum alkaline phosphatase activity, and serum urea (bio Merieux), serum creatinine (Spectrum), serum aspartate aminotransferase, and alanine aminotransferase activities (RANDOX), serum albumin, serum total protein, serum triacylglycerol, serum total lipids, and serum uric acid, (ABC-diagnostic).

In a preliminary work the median lethal concentration (LC50) was determined according to Finney, (1964). The determined LC50 was 1 ug/L.

Acute toxicity was conducted according to Parrish, (1995). A total number of 40 apparently healthy male catfish (Clarias Lazera) weighed 95-105 g, and with total body length of 21-25 cm each were used in this experiment. Fish were divided into two main groups. The first main group was subdivided into 3 replicates of 10 fish each, which were exposed to $1 / 2$ LC50 dose of deltamethrin $(0.5 \mathrm{ug} / \mathrm{L})$ for 1 week. The second main group contained 10 fish and served as a control. At the end 
of one week, ten fish from each main group were chosen at random and sacrificed by the transection of the spinal cord (Mahmoud, 1979). Postmortem lesions were recorded. Serum, and internal organs ( liver, and kidneys) samples were collected for histopathological examination.

Chronic toxicity study was performed according to Cooney, (1995). A total number of 120 apparently healthy male catfish (Clarias Lazera) weighed 95-105g each, and with total body length of 21-25 cm each were used in this experiment. Fish were divided into two main groups. The first main group contained 80 fish, which was subdivided into two equal sub groups. The first sub group (4 replicates, 10 fish each) was exposed to $1 / 50 \mathrm{LC} 50(0.02 \mathrm{ug} / \mathrm{L})$, and the second sub group (4 replicates, 10 fish each) was exposed to 1/100 LC50 of deltamethrin $(0.01 \mathrm{ug} / \mathrm{L})$. The second main group contained 40 fish (4 replicates, 10 fish each) was kept as a control. At the end of 4 weeks, ten fish from each subgroup and control were sacrificed. Furthermore, post-mortem lesions were recorded. Serum and internal organs (liver, and kidneys) samples were collected and immediately fixed in $10 \%$ neutrally buffered formalin solution (Bancroft \& Gamble, 2005) for the histopathological examination.

Histopathological techniques: Tissue specimens washed from formalin, then processed in routine paraffin embedding technique, paraffin blocks were prepared, then paraffin section cut with 3-5 microns thick and stained with haematoxyline and eosin stain (Bancroft \& Gamble, 2005).

Statistical analysis: biochemical parameters were statistically analyzed using the General Linear Models (GLM) procedure of the Statistical Analysis System (SAS, 1999). The statistical model included the effects of treatment. Means were compared using the Duncan's Multiple Range test of the same program. 


\section{RESULTS}

Liver function: The acute exposure to the concentration $0.5 \mathrm{ug} / \mathrm{L}$ of deltamethrin (DM) for 1 week induced non-significant difference in serum total bilirubin, total globulins (S.G.), serum albumin/globulin (A/G ratio), serum triglycerides (TG) levels, serum alanine aminotransferase (S.ALT), and serum alkaline phosphatase (S.ALP) activities, while significantly $(\mathrm{P} \leq 0.05)$ increased serum albumin (S.A.), serum total protein (S.T.P.), serum aspartate aminotransferase (S.AST), lactate dehydrogenase (S.LDH) activities, and significantly decreased serum total cholesterol, serum total lipids (TL) levels. Furthermore, both concentrations 0.02 , and $0.01 \mathrm{ug} / \mathrm{L}$ of $\mathrm{DM}$ significantly $(\mathrm{P} \leq 0.05)$ increased serum total bilirubin, serum AST, ALT, ALP, LDH activities, while significantly $(\mathrm{P} \leq 0.05)$ decreased S.A., S.T.P., A/G ratio, and induced non-significant difference in S.G. content. The concentration $0.01 \mathrm{ug} / \mathrm{L}$ of DM only significantly increased serum cholesterol, TG, and TL levels, while, the concentration $0.02 \mathrm{ug} / \mathrm{L}$ significantly $(\mathrm{P} \leq$ 0.05 ) decreased the serum cholesterol level, and TG, and TL levels during the same week, as compared to the values of the control groups (Table 1, 2 and 3).

Table (1): Effect of deltamethrin on liver functions (Serum total bilirubin, and serum protein fractions).

\begin{tabular}{|c|c|c|c|c|c|}
\hline Groups & $\begin{array}{c}\text { serum total } \\
\text { bilirubin }(\mathrm{mg} / \mathrm{dl})\end{array}$ & $\begin{array}{c}\text { Serum albumin } \\
(\mathrm{S} . \mathrm{A})(\mathrm{gm} / \mathrm{dl})\end{array}$ & $\begin{array}{c}\text { serum total } \\
\text { proteins (S.T.P) } \\
(\mathrm{gm} / \mathrm{dl})\end{array}$ & $\begin{array}{c}\text { Serum total } \\
\text { globulins } \\
\text { (S.G.) }(\mathbf{g m} / \mathbf{d l})\end{array}$ & $\begin{array}{c}\text { Serum albumin / } \\
\text { globulin ratio } \\
\text { (A/G ratio) }\end{array}$ \\
\hline Acute toxicity & & & & & \\
\hline Control & $0.38 \pm 0.02$ & $1.38 \pm 0.01$ & $2.44 \pm 0.03$ & $1.06 \pm 0.03$ & $1.31 \pm 0.04$ \\
\hline $0.5 \mathrm{ug} / \mathrm{L}$ & $0.40 \pm 0.01 \mathrm{~ns}$ & $1.45 \pm 0.01 *$ & $2.57 \pm 0.02 *$ & $1.12 \pm 0.01 \mathrm{~ns}$ & $1.30 \pm 0.02 \mathrm{~ns}$ \\
\hline $\begin{array}{l}\text { Chronic toxicity } \\
\text { control }\end{array}$ & $0.401 \pm 0.003 \mathrm{~B}$ & $1.40 \pm$ & 2.49 & $1.09 \pm$ & $1.28 \pm 0.04 \mathrm{~A}$ \\
\hline $0.02 \mathrm{ug} / \mathrm{L}$ & $0.474 \pm 0.003 \mathrm{~A}$ & $1.02 \pm 0.03 \mathrm{~B}$ & $2.05 \pm 0.04 \mathrm{~B}$ & $1.03 \pm 0.02 \mathrm{~A}$ & $1.00 \pm 0.04 \mathrm{~B}$ \\
\hline $0.01 \mathrm{ug} / \mathrm{L}$ & $0.455 \pm 0.004 \mathrm{~A}$ & $1.00 \pm 0.03 \mathrm{~B}$ & $2.02 \pm 0.04 \mathrm{~B}$ & $1.02 \pm 0.02 \mathrm{~A}$ & $0.99 \pm 0.03 \mathrm{~B}$ \\
\hline
\end{tabular}

Values are means \pm standard errors.

$\mathrm{ns}=$ Not significant $(\mathrm{P}>0.05) ; *=$ Significant at $\mathrm{P} \leq 0.05$.

Means within the same column (groups within period) followed by different capital letter differ significantly at $\mathrm{P} \leq 0.05$. 
Table (2): Effect of deltamethrin on liver functions (Lipid profile).

\begin{tabular}{||l||c||l||l||}
\hline \multicolumn{1}{|c|}{ parameters } & $\begin{array}{c}\text { serum total cholesterol } \\
(\mathbf{m g} / \mathbf{d l})\end{array}$ & $\begin{array}{c}\text { serum triacylglyceroles } \\
\text { (TG) }(\mathbf{m g} / \mathbf{d l})\end{array}$ & $\begin{array}{c}\text { serum total lipids } \\
\text { (TL) (mg/dl) }\end{array}$ \\
\hline \hline Acute toxicity & $156.00 \pm 3.13$ & $124.00 \pm 3.57$ & $469.60 \pm 2.26$ \\
Control & $145.10 \pm 2.74 *$ & $11.00 \pm 3.56 \mathrm{~ns}$ & $460.00 \pm 2.69 *$ \\
$0.5 \mathrm{ug} / \mathrm{L}$ & & & \\
Chronic toxicity & $157.1 \pm 3.20 \mathrm{~B}$ & $105.0 \pm 2.00 \mathrm{C}$ & $473.0 \pm 5.69 \mathrm{~B}$ \\
control & $142.0 \pm 3.06 \mathrm{C}$ & $138.0 \pm 2.47 \mathrm{~A}$ & $450.0 \pm 4.36 \mathrm{C}$ \\
$0.02 \mathrm{ug} / \mathrm{L}$ & $176.6 \pm 3.56 \mathrm{~A}$ & $493.0 \pm 5.43 \mathrm{~A}$ \\
$0.01 \mathrm{ug} / \mathrm{L}$ & & \\
\hline
\end{tabular}

Values are means \pm standard errors.

$\mathrm{ns}=$ Not significant $(\mathrm{P}>0.05) ; *$ Significant at $\mathrm{P} \leq 0.05$.

Means within the same column (groups within period) followed by different capital letter differ significantly at $\mathrm{P} \leq 0.05$.

Table (3): Effect of deltamethrin on liver functions (Serum enzyme activities).

\begin{tabular}{||l||c||c||c||c||}
\hline parameters & $\begin{array}{c}\text { Serum aspartate } \\
\text { Aminotransferase } \\
\text { (S. AST) activity } \\
\text { (U/L) }\end{array}$ & $\begin{array}{c}\text { serum alanine } \\
\text { aminotransferase } \\
\text { (S. ALT) activity } \\
\text { (U/L) }\end{array}$ & $\begin{array}{c}\text { serum alkaline } \\
\text { Phosphatase } \\
\text { (S. ALP) activity } \\
\text { (U/L) }\end{array}$ & $\begin{array}{c}\text { serum lactate } \\
\text { dehydrogenase } \\
\text { (S. LDH) activity } \\
\text { (U/L) }\end{array}$ \\
\hline \hline Acute toxicity & $96.40 \pm 2.08$ & $17.50 \pm 1.07$ & $22.10 \pm 1.16$ & $177.10 \pm 1.43$ \\
Control & $115.00 \pm 1.78^{*}$ & $19.10 \pm 1.42 \mathrm{~ns}$ & $23.50 \pm 1.20 \mathrm{~ns}$ & $198.40 \pm 1.86^{*}$ \\
$0.5 \mathrm{ug} / \mathrm{L}$ & & & \\
Chronic toxicity & $98.8 \pm 1.28 \mathrm{C}$ & $17.3 \pm 0.73 \mathrm{C}$ & $21.0 \pm 0.99 \mathrm{C}$ & $175.8 \pm 1.60 \mathrm{~B}$ \\
control & $110.9 \pm 1.51 \mathrm{~A}$ & $38.6 \pm 1.47 \mathrm{~A}$ & $37.4 \pm 1.24 \mathrm{~A}$ & $192.1 \pm 1.30 \mathrm{~A}$ \\
$0.02 \mathrm{ug} / \mathrm{L}$ & $105.0 \pm 1.61 \mathrm{~B}$ & $26.4 \pm 1.42 \mathrm{~B}$ & $29.9 \pm 1.26 \mathrm{~B}$ & $189.0 \pm 1.99 \mathrm{~A}$ \\
$0.01 \mathrm{ug} / \mathrm{L}$ & & &
\end{tabular}

Values are means \pm standard errors.

ns $=$ Not significant $(\mathrm{P}>0.05) ; \quad *=$ Significant at $\mathrm{P} \leq 0.05$.

Means within the same column (groups within period) followed by different capital letter differ significantly at $\mathrm{P} \leq 0.05$.

Kidney function: The acute exposure to deltamethrin (DM) concentration of $0.5 \mathrm{ug} / \mathrm{L}$ for 1 week significantly $(\mathrm{P} \leq 0.05)$ increased serum urea content, and significantly increased serum creatinine (S.Cr.) concentration, while both concentrations 0.02 and $0.01 \mathrm{ug} / \mathrm{L}$ of $\mathrm{DM}$ significantly $(\mathrm{P} \leq 0.05)$ increased serum urea, and serum uric acid content. The concentration $0.02 \mathrm{ug} / \mathrm{L}$ of DM only significantly increased S.Cr. as compared to the values of the control groups (Table 4). 
Effect Of Deltamethrin On Liver And Kidney Function Of.

Table (4): Effect of deltamethrin on kidney functions.

\begin{tabular}{|l||l||l||c||}
\hline Groups & $\begin{array}{c}\text { serum urea } \\
(\mathbf{m g} / \mathbf{d l})\end{array}$ & $\begin{array}{c}\text { serum creatinine } \\
(\mathbf{S . C r} .)(\mathbf{m g} / \mathbf{d l})\end{array}$ & $\begin{array}{c}\text { Serum uric acid } \\
(\mathbf{m g} / \mathbf{d l})\end{array}$ \\
\hline \hline Acute toxicity & & & $1.50 \pm 0.003$ \\
Control & $2.60 \pm 0.16$ & $0.70 \pm 0.002$ & $1.56 \pm 0.003^{*}$ \\
$0.5 \mathrm{ug} / \mathrm{L}$ & $4.20 \pm 0.12^{*}$ & $0.77 \pm 0.006^{*}$ & $1.50 \pm 0.02 \mathrm{~B}$ \\
Chronic toxicity & & $0.702 \pm 0.008 \mathrm{~B}$ & $1.59 \pm 0.02 \mathrm{~A}$ \\
$\operatorname{control}$ & $2.40 \pm 0.19 \mathrm{C}$ & $0.764 \pm 0.007 \mathrm{~A}$ & $1.57 \pm 0.02 \mathrm{~A}$ \\
$0.02 \mathrm{ug} / \mathrm{L}$ & $3.90 \pm 0.18 \mathrm{~A}$ & $0.710 \pm 0.003 \mathrm{~B}$ & \\
$0.01 \mathrm{ug} / \mathrm{L}$ & $3.30 \pm 0.24 \mathrm{~B}$ & & \\
\hline
\end{tabular}

Values are means \pm standard errors.

$\mathrm{ns}=$ Not significant $(\mathrm{P}>0.05) ; \quad *=$ Significant at $\mathrm{P} \leq 0.05$.

Means within the same column (groups within period) followed by different capital letter differ significantly at $\mathrm{P} \leq 0.05$.

\section{Histopathological findings:}

Liver: The microscopic examination for the liver was studied in comparison to the normal histological structure in control livers (Fig. 1). After the acute exposure to the concentration $0.5 \mathrm{ug} / \mathrm{L}$ of $\mathrm{DM}$ for oneweek, excess of melano-machrophage centers (MMCs), congestion, odema and lymphocytic infiltrations were seen (Fig. 2). The chronic exposure to the low concentration $0.01 \mathrm{ug} / \mathrm{L}$ of $\mathrm{DM}$ led to excess of hepatocytic vacuolar degenerations, congestion and lymphocytic aggregations were seen (Fig. 3). The chronic exposure to the high concentration $0.02 \mathrm{ug} / \mathrm{L}$ of deltamethrin led to congestion with severe hydropic degeneration and necrosis of the hepatic cells and excess of MMCs (Fig. 4). 
M. A. Aziz et al.,

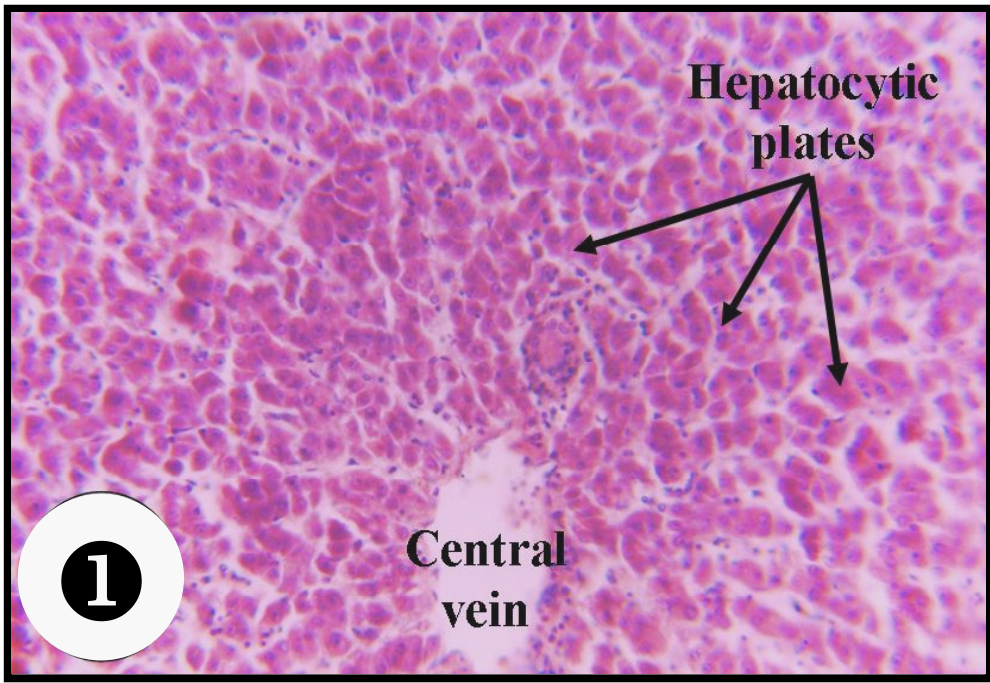

Fig (1): Section in the liver of control male catfish (Clarias lazera), showing normal hepatocytic Plates arranged with central vein, $(\mathrm{H} \& \mathrm{E} . \times$ 250).

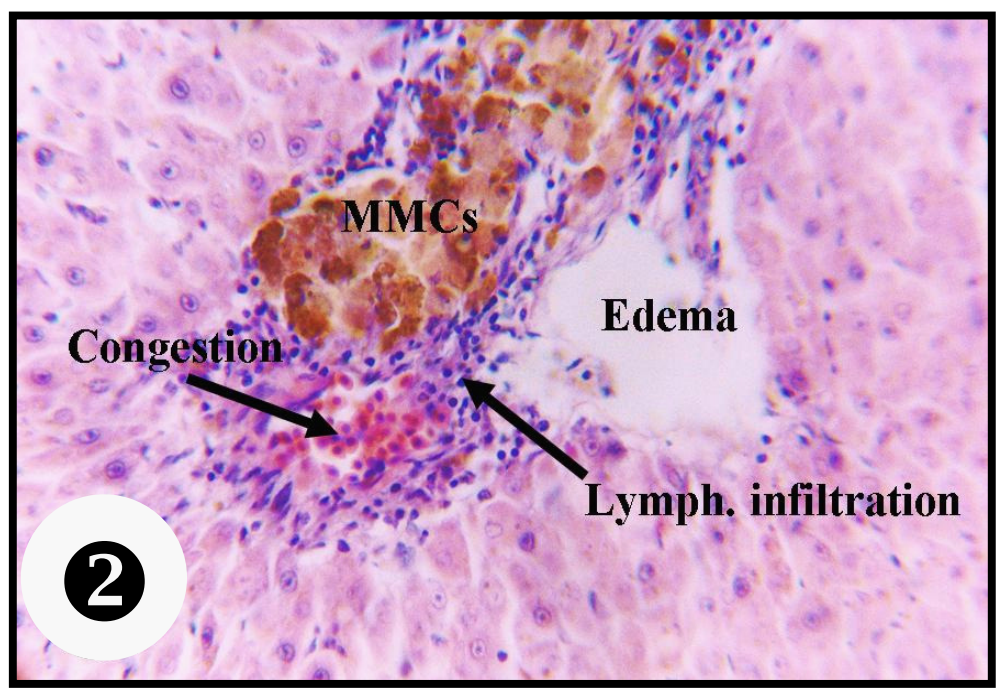

Fig (2): Section in the liver of male catfish (Clarias lazera), exposed to deltamethrin concentration of $0.5 \mathrm{ug} / \mathrm{L}$ for 1 week showing excess of melano macrophage centers (MMCs), congestion, odema and lymphocytic infiltrations (H \& E, × 400). 


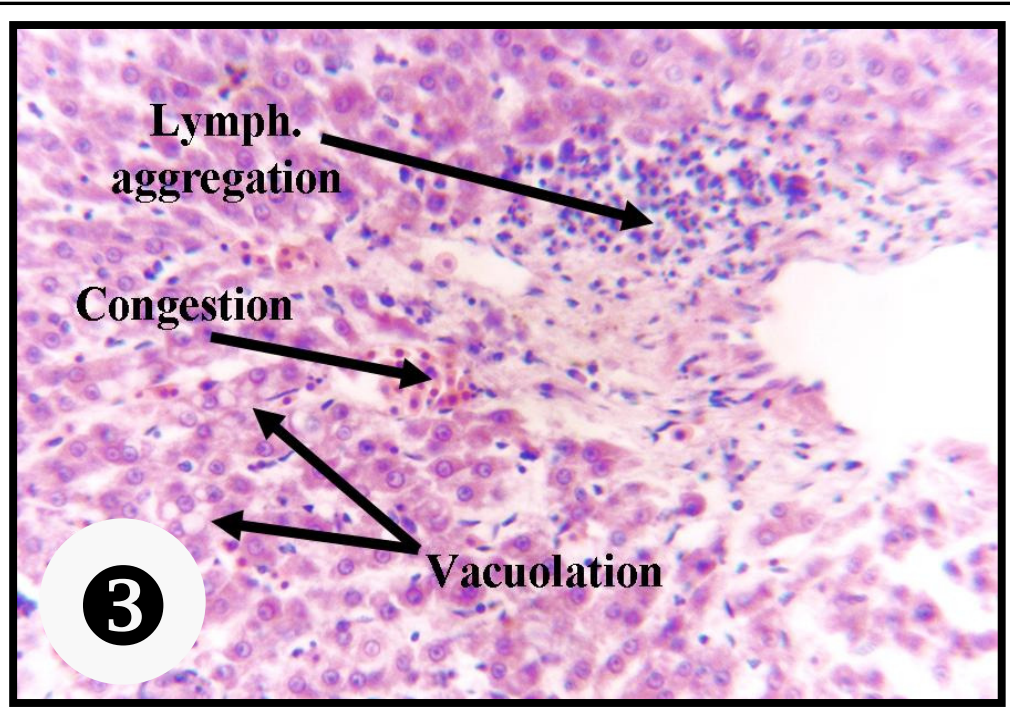

Fig (3): Section in the liver of male catfish (Clarias lazera), exposed to deltamethrin concentration of $0.01 \mathrm{ug} / \mathrm{L}$, showing hepatocytic vacuolations, congestion and Lymphocytic aggregations $(\mathrm{H} \& \mathrm{E}, \times 400)$.

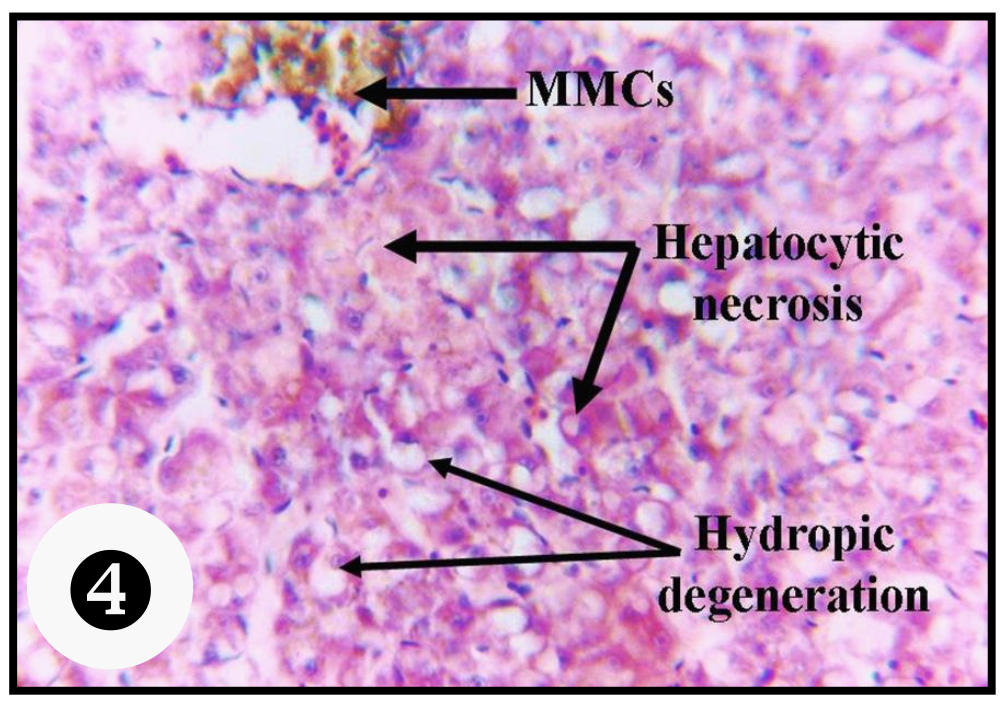

Fig (4): Section in the liver of male catfish (Clarias lazera), exposed to deltamethrin concentration of $0.02 \mathrm{ug} / \mathrm{L}$, showing congestion, severe hepatocytic hydropic degeneration, necrosis and excess of melanomacrophage centers $(\mathrm{H} \& \mathrm{E}, \times 400)$. 
Kidney: The histopathologic alterations in the kidneys of intoxicated catfish were also differentially studied with the normal histology of kidney in control group (Fig. 5). After acute exposure to the concentration $0.5 \mathrm{ug} / \mathrm{L}$ of deltamethrin for one week, the renal tubules were damaged and appeared associated with congestion of the various glomerular as well as intertubular blood vessels in addition to several areas of hemorrhages and lymphocytic infiltrations (Fig. $6)$. The posterior kidneys after chronic exposure to the high concentration $0.02 \mathrm{ug} / \mathrm{L}$ of deltamethrin suffered damage of the glomeruli with several tubular degenerations and necrosis in addition to an excess of mononuclear cell reactions (Fig. 7).

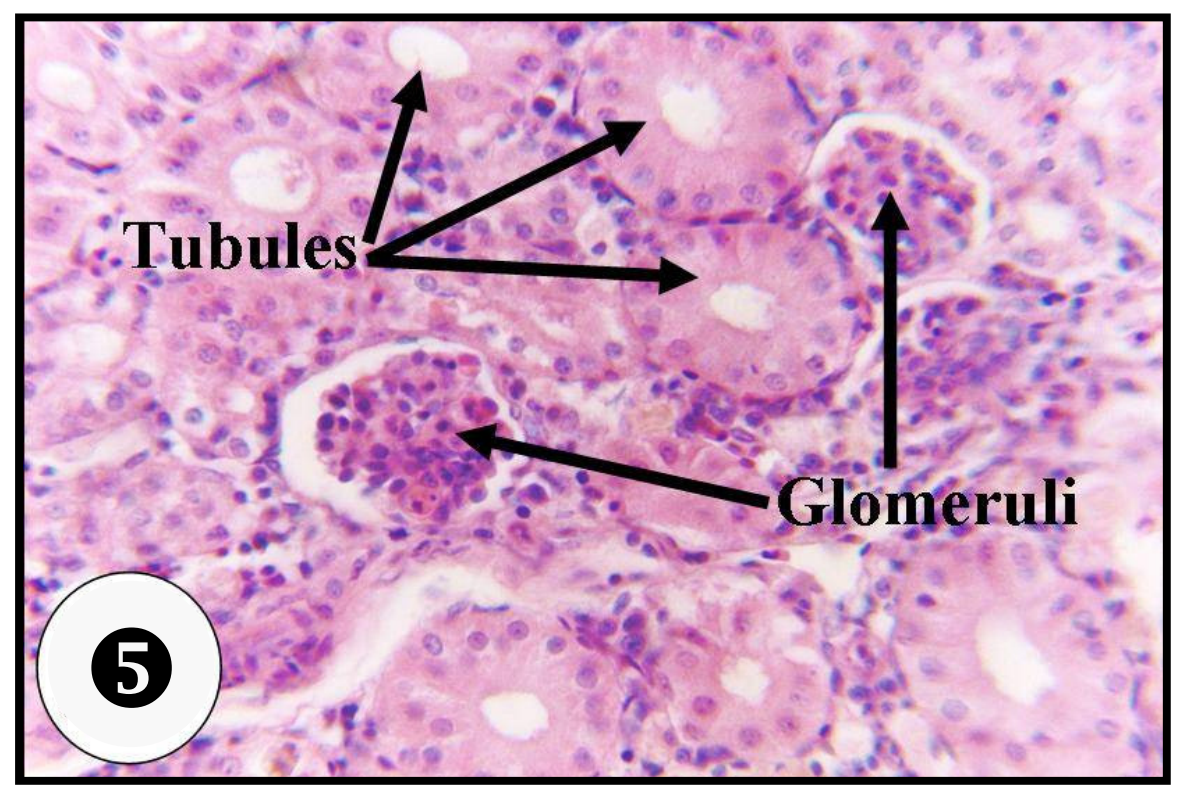

Fig (5): Section in the kidney of control male catfish (Clarias lazera), showing normal histological parameters for renal glomeruli and tubules $(\mathrm{H} \&$ E, $\times 400)$. 


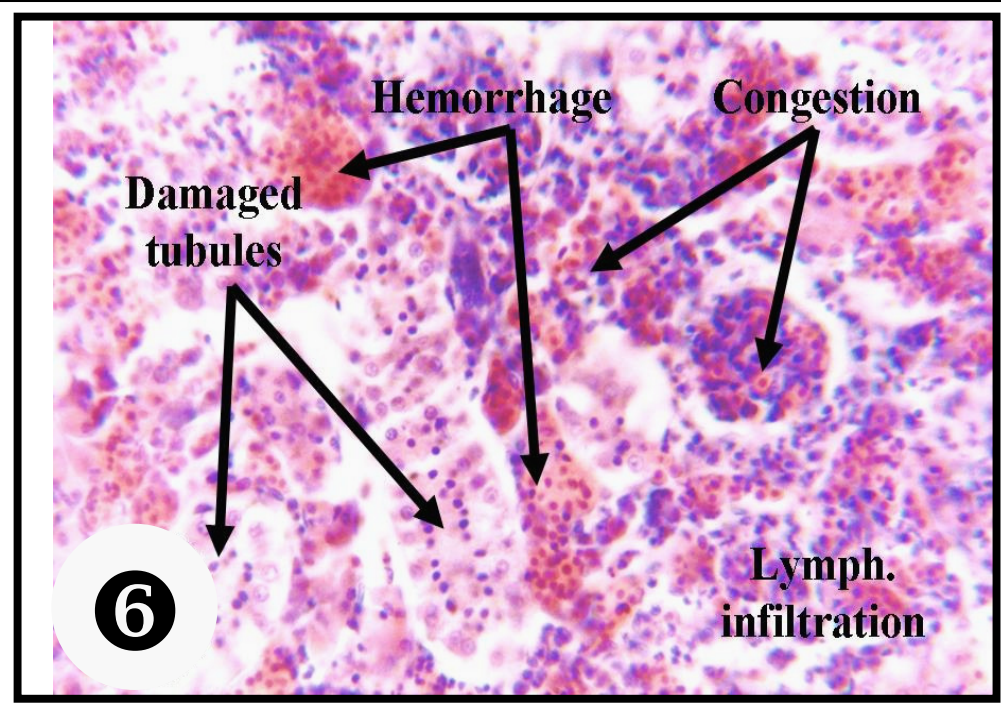

Fig (6): Section in the kidney of male catfish (Clarias lazera), exposed to deltamethrin concentration of $0.5 \mathrm{ug} / \mathrm{L}$ for 1 week, showing damaged renal tubules, congested glomeruli and intertubular capillaries, haemorrhages and Lymphocytic infiltrations (H \& E, × 400).

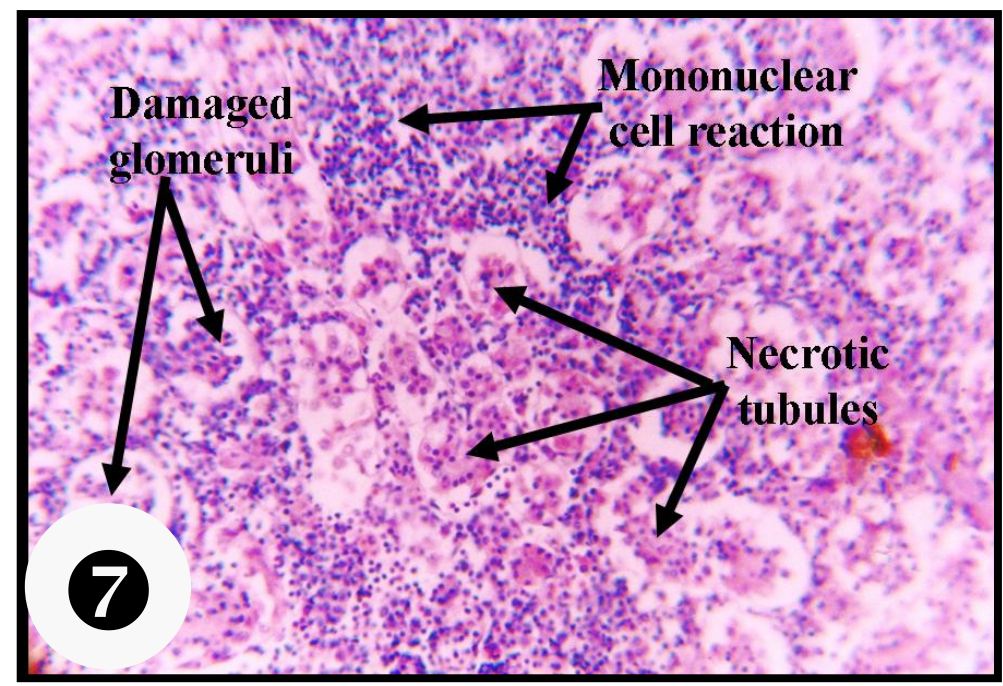

Fig (7): Section in the posterior kidney of male catfish (Clarias lazera), exposed to deltamethrin concentration of $0.02 \mathrm{ug} / \mathrm{L}$, showing damaged glomeruli, necrotic tubules, and excess of mononuclear cell reactions $(\mathrm{H} \& \mathrm{E}, \times 250)$. 


\section{DISCUSSION}

Deltamethrin (DM) can enter the aquatic environment by several routes and it is more toxic to fish than mammals. Fish seem to be deficient in the enzyme system that hydrolyzes pyrethroids, in addition to its lipophilicity, which facilitates its penetration from the surrounding water through all the biological membranes of fish. Deltamethrin also represents a strong stressor on fish due to its induction of catecholamine release (Viran et al., 2003 and EL-Sayed and Saad, 2008).

Serum bilirubin results from the breakdown of haem by cells of mononuclear phagocytic system. In the absence of haemolysis, hyperbilirubinemia is an indication that the liver is not functioning properly (Hall, 1992). Deltamethrin induced hyperbilirubinemia by chronic exposure in the present study was in agreement with the findings of Yousef et al, (2006) in 24 male Sprague Dawely rats, which were administered deltamethrin daily dose of $1.28 \mathrm{mg} / \mathrm{kg} \mathrm{b.w}$. for 30 days. They attributed serum hyperbilirubinaemia to deltamethrin impairment effect on liver function, which could potentially decrease liver bilirubin uptake or conjugation. hyperbilirubinaemia could also be due to deltamethrin damaging effect on hepatocytes, or onset of liver necrosis. Murray et al., (1991) attributed the total hyperbilirubinaemia to chronic hepatitis as a result of hepatotoxic reaction to some drugs or toxins. The previously mentioned fact could be confirmed by the liver histopathological findings in this study, where hepatocytic vaculation, congestion, lymphocytic infiltrations, hepatocytic necrosis and excess of melanomacrophage centers (MMCs) were seen by chronic exposure to deltamethrin. 
As it was observed from liver histopathological picture, vacular hydropic degeneration of hepatocytes may be another cause of total hyperbilirubinaemia. Hydropic degeneration may be due to hypoxia and chemical poisoning, and characterized by cell swelling as a result of accumulation of fluids inside cells and pressure obstruction of small bile canaliculi (Underwood, 1992), and so cause intra hepatic obstruction of bile flow and consequently hyper bilirubinaemia and usually is associated with higher alkaline phosphatase activity (Hall, 1992, and Murray et al., 1991). Swollen hepatocytes also have impaired ability to secrete conjugated bilirubin and may end in cell death and so impairment of the cell function as a whole. This was indicated by Cheville, (2006) and compared by hepatocytic necrosis in this study.

Excess melano macrophage centers (MMCs) were noticed in liver. MMCs are integral part of the reticulo endothelial system of fish. Considering species difference, MMCs are analogy with the lymph node found in mammals. Pigments may be present as an indigestible residues because of that, intracellular digestive process of fish macrophages may not be well developed on the evolutionary scales as mammals. Cytologically melano-macrophage centers consist of aggregations of reticular cells, lymphocytes, pigment carrying phagocytic macrophage cells and plasma cells (Agius, 1985, and Stoskopf, 1993a). Pigment carrying cells are so commonly increased at sites of tissue injury. It was thought that, melanin can act as a biological electron exchange polymer and thus protecting cells against reducing or oxidizing conditions, which might release highly reactive free radicals. The possible mobilization of melanin in order to neutralize free radicals, cations, and iron, as iron known to catalyze the peroxidation of lipids in animal tissues, including fish, indicated that, MMCs were involved in the immune response. That was in agreement with the findings of the present study, and also that recorded by Agius, (1985) and Stoskopf, (1993a). 
Albumin is the most abundant individual protein and is largely responsible for maintaining intravascular pressure. Albumin also serves as a storage reservoir of amino acids and as a transport protein, binding most plasma constituents that do not have a specific transport protein, (Hall, 1992). Liver function tests revealed, an elevation in the serum albumin levels by the acute exposure, which may indicate dehydration due to haemoconcentration as referred by Hall, (1992), while decreased serum albumin level by the chronic deltamethrin exposure was in agreement with the findings of El-Sayed and Saad, (2008) who thought it to be due to, impaired albumin synthesis as in chronic hepatic insufficiency or hepatitis and chronic renal affections. However, a statistically significant decrease in the serum albumin concentration is the one of the most frequent findings in toxicology studies (Hall, 1992 and Murray et al, 1991).

The recorded hyperproteinaemia in this study disagreed with the findings of Svobodovà et al., (2003) which may be due to the difference of fish species, the periods of exposure, insecticide formulations, concentrations, and conditions under which the tests were performed. The induced hyperproteinemia which was associated with higher albumin level, suggested dehydration of catfish exposed to deltamethrin concentration of $0.5 \mathrm{ug} / \mathrm{L}$ for one week as it was indicated by Coles (1986) and Hall, (1992). However, hypoproteinaemia, like anaemia can be masked by dehydration (Hall, 1992). Elevated serum total protein level could be also attributed to destruction and disintegration of tissue that was exposed to toxic pollutants (Whicher, 1983), which was supported by histopathological findings of the present study. 
The recorded hypoproteinemia by deltamethrin chronic exposure was in agreement with the findings of El-Sayed and Saad, (2008) who attributed it to damaging effect of deltamethrin on liver cells, which impaired the protein synthesis. Moreover the same explanation was also introduced by Hosny et al, (1989). Also hypoprotenimia in this study followed hypoalbuminemia, so it may have resulted from the same causes of hypoalbuminaemia previously mentioned as it was indicated by Murray et al, (1991), and Hall, (1992).

A non significant difference in serum globulin level by both the acute and chronic exposures was in full agreement with the findings of Velisek et al., (2006), and partially coincided with the findings of $\boldsymbol{E l}$ Sayed and Saad (2008), who found only a non significant difference of gloublin level at both the $1^{\text {st }}$, and $3^{\text {rd }}$ weeks in the serum of 4 weeks deltamethrin exposed Oreochromis niloticus fish, even that, the findings were not on line with results achieved by Taha, (2002) in albino rats. The decreased serum globulin level by deltamethrin exposure was attributed to the decrease of the level of gamma globulin G (IgG) as found by Kowalczyk - Broniz et al, (1990) who administered mice deltamethrin for 30 days. Considering species difference and in contrast to mammals, fish are lacking the $\mathrm{IgG}$, which is the target immunoglobulin of deltamethrin. The immuno macroglobulin (IgM) isotype is essentially the only immunoglobulin present in bony fish and generally exists as a tetramer, this is also in contrast to that of mammals which is a pentamer as mentioned by Jurd, (1985); Tucker\& Robinson, (1990); Stoskopf, (1993a); Anderson \& Zeeman, (1995) and Bernstein et al., (1998). 
Indeed, fish places a greater emphasis on the non-specific defense response than mammals. Because of that, fish are not capable of mammalian type secondary response, characterized by a switch from IgM to different classes of antibodies showing higher affinity for the antigen as $\operatorname{IgG}, \operatorname{Ig} \mathrm{A}, \operatorname{IgE}$, and $\mathrm{IgD}$. Moreover fish have a short life span in comparison to mammals (Jurd, 1985; Anderson \& Zeeman, 1995, and Bernstein et al, 1998).

A significant decrease in serum albumin /globulin ratio was recorded only by the chronic exposure to deltamethrin. A/G ratio is often below one in liver affections (Peterman, 1960), which can be confirmed by hepatic findings of this study.

Serum cholesterol is derived from dietary intake and endogenous synthesis, primarily by the liver. Also the liver via the biliary system is the major excretory pathway for cholesterol (Hall, 1992). Decreased serum cholesterol level by acute exposure, may have resulted from acute hepatitis (Murray et al, 1991) supported by liver histopathological findings and liver function tests of the present study. Generally hypochlesterolemia at both acute or chronic exposure to the concentration $0.02 \mathrm{ug} / \mathrm{L}$ of deltamethrin only at the 4th week, may have resulted from malnutrition due to decreasing food intake, malassimillation of food or anaemia (Murray et al., 1991 and Hall, 1992), which were also confirmed with results of this study. Finally cholesterol metabolism is intimately associated with lipid metabolism, so serum cholesterol and triglycerids concentrations must be interpreted collectively (Murray et al, 1991).

Triglycerides serve as an important source of energy. Serum triglycerides are derived from dietary intake and primarily the liver carried out endogenous synthesis. In circulation, triglycerides are 
components of chylomicrons and lipoprotein (Hall, 1992). Serum triglycerides level decrement only by the concentration $0.02 \mathrm{ug} / \mathrm{L}$ of deltamethrin at the 4 th week, may be occurred with parenchymal liver disease, which also was supported by the finding of this study.

Also in the present investigation, a significant decrease in serum total lipids by the deltamethrin acute exposure, and by the concentration $0.02 \mathrm{ug} / \mathrm{L}$ of deltamethrin, and a significant increase only by the chronic exposure to the concentration $0.01 \mathrm{ug} / \mathrm{L}$ of deltamethrin was recorded. These findings were in agreement with the findings of Yousef et al., (2006).

Collectively, Deltamethrin induced hyperglycemia may affect the lipid metabolism (Taha, 2008). Fat is absorbed from the diet in the form of chylomicrons, which contained both triglycerides and cholesterol, but it is rich in triglycerides than cholesterol. While hepatocytes synthesized lipoproteins (very low density lipoproteins) are rich in cholesterol than triglycerides, in addition it contains total lipids.

Deltamethrin induced hyperglycemia may have resulted from its inhibition effect on insulin secretion (Macdonald et al., 2005). Insulin deficiency causes excessive mobilization of free fatty acids (FFA), which consequently increase cholesterol, triglycerides, and total lipids level in the blood (Murray et al.,1991 and Hall,1992). On the other hand starvation and liver disease decreases the serum cholesterol, triglycerides, and total lipids level supported by the findings of this study.

Considering serum enzyme activities, serum aspartate aminotransferase (AST), serum alanine aminotransferase (ALT) and lactate dehydrogenase (LDH) are intracellular enzymes involved in amino acid and/or 
carbohydrate metabolism. The distribution of these enzymes varies in the different organs. Elevations of concentration of these enzymes in blood indicate necrosis or other pathological affections especially of these organs (Murray et al, 1991).

The results of this study revealed a significant increase in the serum AST activity by the acute and chronic deltamethrin exposure, which agreed with the findings of Nemcsok et al., (1999); Szegletes et al., (1995) in deltamethrin exposed carp; Velisek et al., (2006) and El. Sayed and Saad, (2008). Serum AST is present in all tissues of the body, it is not an organ specific enzyme and consequently may be utilized to detect destruction in a wide variety of tissues including liver (Coles, 1986 and Hall, 1992). Nemcsok et al., (1999) attributed the elevated serum AST activity of eel (Anguella anguella) to liver damage. However other organs as kidney may have also been damaged. El-Sayed and Saad (2008) came to the same conclusion, which agreed with the liver, and kidney findings of this study.

The non significant increase in serum ALT by deltamethrin acute exposure was in agreement with the findings of Nemscok et al., (1999), while the elevated serum ALT activity by the chronic exposure was in agreement with the findings of Velisek et al., (2006) and El-Sayed and Saad, (2008). Serum ALT enzyme is present in many tissues, but in a high concentration within the hepatocytes of most species, so its activity is increased in serum by degeneration or destruction of the hepatocytes mainly (Coles, 1986, and Hall, 1992). The level of enzymes depends on a number of factors as concentration gradient between cell and serum. ALT may leak into serum in any condition that alters membrane permeability to a sufficient degree. ALT leakage is according to concent- 
ration gradient from the higher intracellular concentration to the lower serum extra cellular concentration, even in reversible conditions. Leakage doesn't require cell death, and elevated activity doesn't imply necrosis. The magnitude of serum activity elevation is proportional to the number of affected hepatocytes (Hall, 1992).

Velisek et al., (2006), attributed elevated serum AST, and ALT levels to deltamethrin induced toxic stress, which amplified transamination processes due to amino acid input into the tricarboxylic acid cycle in order to cope with the energy crisis during deltamethrin based stress.

A significant increase in serum alkaline phosphatase (AP) level was recorded only in the chronic toxicity study. These findings coincided with that of El-Sayed \& Saad, (2008) who attributed it to the damaging effect of deltamethrin on the liver. Alkaline phosphatase (AP) is present in high concentrations in blood. The higher serum concentration of AP in this study may be due to cell swelling as a result of deltamethrin induced hydropic degeneration, which may lead to pressure obstruction of small bile ductules, where primary hepato cellular toxicities can cause enough intrahepatic cholestasis to elevate serum AP activity (Hall, 1992, and Murray et al., 1991). No elevation was recorded in the serum alkaline phosphatase level by the deltamethrin acute exposure. That may be due to absence of hepatocellular degenerative changes and cellular swelling.

A significant increase in serum lactate dehydrogenase (LDH) activity was recorded by both the acute and chronic deltamethrin exposure. LDH enzyme is distributed generally in body cells and fluids. Its serum concentration was elevated in all the conditions accompanied by tissue necrosis including liver also it was elevated in acute hepatitis (Murray et al., 1991), which agreed with histopathologyical findings of this study. The elevated serum LDH activity was in agreement with the 
findings of Nemcsok et al., (1999), who observed a significant increase in LDH level in the serum of deltamethrin exposed eel (Anguilla anguilla) of an extent they had never observed before, and supposed that the increased LDH activity could indicate not only tissue necrosis, but also metabolic changes in the stressed fish, primarily in cells, where the catabolism of glycogen and glucose is shifted towards the formation of lactate. Elevated serum LDH activites also were in agreement with findings of Velisek et al., (2006) who attributed increased serum level of LDH, ALT, and AST of deltamethrin exposed common carp (Cyprinus carpio L.) to stress based tissue impairment, as activities of these enzymes are used as a relevant stress indicator, where the increase in LDH level indicates metabolic changes, i.e. glycogen catabolism and glucose shift towards the formation of lactate in stressed fish, primarily in the muscle tissue.

The kidney function tests revealed a significant increase in serum urea by both deltamethrin acute, and chronic exposure. The previous findings were in agreement with the results obtained by Yousef et al., (2006). Serum urea nitrogen elevations may indicate kidney disease (Hall, 1992), which was in agreement with findings of this study where there is renal lesions in case of the concentration $0.02 \mathrm{ug} / \mathrm{L}$ of deltamethrin only. Damage of gloumeruli with several tubular degenerations and necrosis and excess mononuclear cell reactions were seen in the posterior kidney of catfish chronically exposed to the concentraion $0.02 \mathrm{ug} / \mathrm{L}$ of deltamethrin.

Susceptibility of the kidney to chemically induced toxicity is related in part to several unique aspects of renal anatomy and physiology. By virtue of high renal blood flow, concentration of chemicals in the intraluminal fluid, reabsorption and / or secretion of chemicals through 
tubular cells, and sometimes may biotransformation of protoxicants to reactive intermediates (Joan et al., 1994). In addition to that, deltamethrin is mainly excreted through the kidney (Wang et al., 2007).

A significant increase in serum creatinine concentration by deltamethrin acute exposure, and only by the concentration $0.02 \mathrm{ug} / \mathrm{L}$ of deltamethrin at the 4th week of exposure was recorded. Elevated serum creatinine level was in agreement with the findings of Yousef et al., (2006). Serum creatinine paralleled changes in serum urea nitrogen concentration caused by alterations in renal blood flow, and renal function (Hall, 1992). These findings disagreed with Taha, (2002) who found only kidney lesions by the dose 1/50 of LD50 without elevation in serum urea or creatinine level, which may be due to that, fish are more susceptible to toxic effect of pyrethroids more than rats. There was no serum creatinine elevation induced by the concentration $0.01 \mathrm{ug} / \mathrm{L}$ of deltamethrin, which was in agreement with the findings of Taha, (2002), who also found that, there was no elevation of the serum creatinine concentration by the dose 1/100 of LD50, because of that, there was no renal lesion recorded. The changes of the kidney function may not be detected until the ability of the kidney to compensate is exceeded. (Joan et al., 1994), as creatinine is insensitive to small affects on kidney. (Coles, 1986).

A significant increase in serum uric acid by both the acute and chronic deltamethrin exposure was recorded. Considering species difference uric acid is formed by fish from exogenous and endogenous purine nucleotide and by the catabolism of proteins via purines, It's converted in the liver, and to a lesser extent in the kidney to urea for excretions by the gills (Stoskopf, 1993), so liver and kidney affections hinders its conversion to urea and so increasing its level in the blood, which is in agreement with the findings of this study. 
In conclusion, the careless agricultural, and veterinary use of deltamethrin may have a role in the environmental pollution by exerting serious effects especially on some aquatic non-target organisms as catfish (Clarias lazera), as it was indicated by this study. Special attention and strict precautions must be given to the correct use of this insecticide within its recommended therapeutic doses to avoid its hazardous effects, and protection of our ecosystem.

\section{REFERENCES}

- Agius, C. (1985): The melano-macrophage centers of fish: A review. In: Fish immunology. Manning, M. J., and Tatner, M. F. (Eds.), Academic Press INC, U. S. A., P. 85- 105.

- Anderson, D. P. \& Zeeman, M. G., (1995): Immunotoxicology in fish. In: Fundamentals of aquatic toxicology, $2^{\text {nd }}$ Ed. Rand, G. M. (Ed.), Taylor \& Francis, U. S. A., P. 371- 404.

- ASTM, (1980): Standard practice for conducting toxicity tests with fishes, macro invertebrates, and amphibians. American Society for Testing and Materials ASTM E 729 - 80, Philadelphia.

- Bancroft, J. D., and Gamble, M., (2005): Theory and practice of histological techniques. Churchill Living Stone, Elsevier limited, China.

- Bernstein, R. M.; Schluter, S. F., and Marchalonis, J. J., (1998): Immunity. In: The physiology of fishes, $2^{\text {nd }}$ Ed. Evan, S. D. H. (Ed.), CRC Press LIC, U. S. A., P. 228- 242.

- Cheville, N. F., (2006): Introduction to veterinary pathology, $3^{\text {rd }}$ Ed., Blackwell Publishing, U. S. A., P. 16- 23. 
- Coles, E. H., (1986): Veterinary clinical pathology, $4^{\text {th }}$ Ed. W. B. Saunders Co. (Inc.), Philadelphia, U. S. A.

- Cooney, J. D., (1995): Freshwater tests. In: Fundamentals of aquatic toxicology, 2nd Ed. Rand, G. M. (Ed.), Taylor \& Francis, U. S. A., P. $71-102$.

- El - Basyouni, S., A., (1985): Studies on the toxicity of some pesticides on mosquito and their side effect on some organisms. Ph. D. Thesis. Fac. Agric., Tanta Univ..

- El-Sayed, Y. S., and Saad, T. T., (2008): Sub acute intoxication of a deltamethrin based preparation (Butox $5 \%$ EC) in monosex Nile tilapia (Oreochromis niloticus L.). Basic. Clin. Pharmacol. Toxicol., 102 (3): 293 - 9.

- Finney, D. J., (1964): Statistical method in biological assay. Charless Griffin and Company limited, London.

- Floyd, R. E., (1993): Clinical pathology of catfish. In: Fish medicine, $1^{\text {st }}$ Ed. Stoskopf, M. K. (Ed.), W. B. Saunders Company, Mexico, P. 502.

- Floyd, R. E., (1993a): Environmental diseases of catfish. In: Fish medicine, $1^{\text {st }}$ Ed. Stoskopf, M. K. (Ed.),W. B. Saunders Company, Mexico, P. 506.

- Hall,R. L.,(1992): Clinical pathology. In: Animal model in toxicology. $1^{\text {st }}$ Ed. Gad, S. C., and Chengelis, C. P. (Eds.), Marsel Dekker (Inc), U.S. A.

- Hosny,A.H.; Salama, M. E., and El-Basyouni, S. A. (1989): Studies on the effect of some insecticides on certain aquaculture organisms (1- toxicity of different insecticides on certain aquatic and body contents of Clarias lazera). J. Agric. Res. Tanta Univ., 15 (1): 96 -111. 
- Joan, B.; Goldstein, T. S., and Goldstein, R. S., (1994): Biochemical mechanisms of renal toxicity. In: Biochemical toxicology, $2^{\text {nd }}$ Ed. Hogson, E., and levi, P. E. (Eds.), Appleton \& Lang, East Norwalk, Connecticut, P. 519- 546.

- Jurd, R. D., (1985): Specialization in the teleost and anuran immune response: A comparative critique. In: Fish immunology. Manning, M. J., and Tatner, M. F. (Eds.), Academic Press INC, U. S. A, P. 17.

- Kowalczyk-Broniz,S.H.;Gieldanowski,J., and Ana Bubak, B.,(1990): Immunological profile of animals exposed to pesticide deltamethrin. Arch. Immune. Ther. Exp., 38: 229- 38.

- Landis, W. G., and Hoyu, M., (1995): Introduction to environmental toxicology - Impacts of chemicals upon ecological systems, $1^{\text {st }}$ Ed., CRC Press, Inc., U. S. A..

- Macdonald, P. E.; Eliasson, L., and Rorsman, P., (2005): Calcium increases endocytotic vesicle size and accelerates membrane fission in insulin - secreting INS - 1 cells, J. Cell Sci., 118 (24): 5911 - 20.

- Mahmoud, A. S., (1979): Toxicological studies of some aquatic weed killers herbicides to Nile fish, M. V. Sc. Thesis. Fac. Vet. Med., Cairo Univ.

- Murray, R. K.; Granner, D. K.; Mayes, P. A., and Rodwell, V. W., (1991): Harper's biochemistry. Appleton \& Lange, Lebanon.

- Nemcsok, K.J.;Blint,T.;Fazakas,J.;Ktai,F.;Kiss.I.;Hieu,L.H.;Kufcs, K. O.; Lng, G.; Polyhos, C., Szab. I., and Azegletes, T., (1999): The contribution of a pyrethroid insecticide to the massive eel (Anguilla anguilla) devastation in lake Balaton, in 1995. Acta Biol. Hung., 50 (1-3): 161- 73 . 
- Noga, E. J., (1996): Fish disease, diagnosis and treatment. $1^{\mathrm{st}}$ Ed., Mosby - Year book, Inc., U. S. A.

- Parrish, P. R., (1995): Acute toxicity tests. In: Fundamentals of aquatic toxicology, $2^{\text {nd }}$ Ed. Rand, G. M. (Eds.), Taylor \& Francis, U. S. A., P. 947- 973.

- Peterman, (1960): cited by: El-leithy, S. S. I., (1985): The effect of lithium treatment on some metabolic aspects in rats. M. Sc. Thesis. Fac. Pharm., Cairo Univ.

- Rehman, H.; Ali, M.; Atif, F.; Kaur, M.; Bhatia, K., and Raisuddin, S., (2006): The modulatory effect of deltamethrin on antioxidants in mice. Clin. Chem. Acta, 369 (1): 61 - 5.

- SAS, (1999): Statistical Analysis System. User Guide: Statistics. SAS Institute Cary, North Carolina.

- Stoskopf, M. K., (1993): Clinical pathology. In: fish medicine, Stoskopf, M. K. (Eds.), W. B. Saunders Company, Mexico, P. 113131.

- Stoskopf, S. K., (1993 a): Immunology. In: fish medicine, Stoskopf, M. K. (Eds.), W. B. Saunders Company, Mexico, P. 149- 159.

- Svobodovà, Z.; Luskovà, V.; Drastichovà, J.; Svoboda, M., and Îlàbek, $V$., (2003): Effect of deltamethrin on haematological indices of common carp (Cyprinus carpio L.). Acta Vet. Brno, 72: 79- 85.

- Szegletes, T.; Polyhos, C. S.; Balint, T.; Rady, A. A.; Lang, G., Kufcsak, O. L., and Nemcsok, J., (1995): In vivo effects of deltamethrin on some biochemical parameters of carp. (Cyprinus carpio L.), Environ. Mon. Ssess., 35: 97 - 111. 
- Taha, M., M., A., (2002): Some toxicological studies on deltamethrin. M. V. Sc. Thesis. Fac. Vet. Med., Tanta Univ.

- Taha, M., M., A., (2008): A toxicological study on deltamethrin, and its role in environmental pollution. Ph. D. Thesis. Fac. Vet. Med., Tanta Univ.

- Tucker, C. S., and Robinson, E. H., (1990): Channel catfish farming handbook, Van Nostrand Reinhold, U. S. A.

- Underwood, J. C. E., (1992): General and systemic pathology, Longman group UK Limited, Hong Kong.

- Velisek,J.;Dovsikova,R.;Svobodova,Z.;Modra,H., and Luskova, V., (2006): Effect of deltamethrin on biochemical profile of common Carp (Cyprinus carpio L.). Bull. Environ. Contam. Toxicol., 76: 992 - 998.

- Viran, R.; Unlu Erkoc, F.; Polat, H., and Kocak, O., (2003): Investigation of acute toxicity of deltamethrin on guppies (Poecilia reticulate). Ecotoxicol. Environ. Saf., 55 (1): 82 - 85.

- Wang, D.; Kamijima, M.; Imai, R.; Suzuki, T.; Kameda, Y.; Asai, K; Okamura, A; Naito, H.; Ueyama, J.; Saito, I.; Nakajima, T.; Goto, M.; Shibata, E.; Kondo, T.; Takagi, K.; Takagi, K., and Wakusawa, S., (2007): Biological monitoring of pyrethroid exposure of pest control workers in Japan. J. Occup. Health, 49 (6): 509 - 14.

- Whicher, J. T., (1983): Abnormalities of plasma protein. In: Biochemistry in clinical practice. Williams D. L., and Marks V. (Eds.), William Heinemann, London, P. 221- 250.

- Yousef,M.I.; Awad, T. I., and Mohamed, E. H., (2006): Deltamethrin induced oxidative damage, and biochemical alterations in rat and its attenuation by vitamin E. Toxicology: $240-247$. 